\title{
Slumping as a record of regional tectonics and palaeoslope changes in the Satpura Basin, central India
}

\author{
Merajuddin Khan*, Ranjit G. Khangar, Nilasree Raychowdhury, \\ Anand T. Babhare \\ Geological Survey of India, Central Region, Seminary Hills, Nagpur-440 006, India \\ *corresponding author; e-mail: meraj.gsi@gmail.com
}

\begin{abstract}
Soft-sediment deformation structures play an important role in interpreting regional tectonics and basin evolution during slumping events. The Satpura Basin is interpreted as pull-apart with a monoclinal northerly palaeoslope throughout its evolution. The basin formed as a result of sinistral strike-slip faulting, induced by the ENE-WSW-trending Son-Narmada South fault in the north and the Tapti North fault in the south. We have analysed the slump folds within the basalmost Talchir Formation and related these to regional tectonics and palaeoslope changes in the Satpura Basin. The glaciofluvial strata of the Talchir Formation, exposed in the southern part of the Satpura Basin, record intricacies of folds created during slumping. Several fold styles can be distinguished, within alternations of competent sandstone and incompetent shale layers, some of which indicate buckling. Upright folds, resulting from pure shear, underwent rotation of their axial planes and fold axes during simple shear-dominated progressive deformation when the slump moved downslope. The soft-sediment deformation structures that we have studied show refolding patterns that closely resemble comparable folds known from lithified rocks. These layers with refolded structures are overlain by undeformed sediments, which proves that they are the product of a single ongoing slumping process, rather than of successive deformation events. Our analysis of their fold axes and axial planes, together with fold vergences and thrust directions within the slumps, suggests a mean slumping direction towards the southwest. Analyses of slump folds and their relationship with regional tectonics have allowed us to reinterpret basin evolution history. The southwesterly trending palaeoslope of the basin suggest that the slope of the basin was not uniform throughout its evolution. At the opening, the oblique slip fault, which trended NE-SW, generated due to movement along the ENE-WSW basin bounding faults, was more active and triggered slumping event within the Talchir deposits in the basin. With progressive overlapping of the basin-bounding faults, the Satpura Basin gradually tilted towards the north.
\end{abstract}

Key words: Soft-sediment deformation structures, fold analysis, refolding, slump folds, Talchir Formation

\section{Introduction}

Soft-sediment deformation structures (SSDS) record evidence of both sedimentary and tectonic processes, whether they occurred during/after sedimentation and before lithification (Seilacher, 1969; Lowe, 1975; Allen, 1984, 1986; Maltman, 1984, 1994a; Leeder, 1987; Pratt, 1994; Obermeier, 1996; 
Van Loon, 2009). SSDS are generally produced by reorganisation of original particles in sediments and sedimentary rocks. Studies of such SSDS have been carried out in a wide range of geological environments, ranging from continental to coastal and marine, spanning from the Palaeoproterozoic to the present time (e.g., Allen, 1984; Maltman, 1994a, 1994b; Maltman et al., 2000; Alfaro et al.,2002; Ettensohn et al., 2002; Mazumder et al., 2006, 2016; Van Loon, 2009, 2014; Perucca et al., 2014; Üner, 2014; Alsop et al., 2017, 2019; Hubert-Ferrari et al., 2017; Byun et al., 2019).

It was long believed that slump folds bore a similarity to folds developed in lithified rocks as a result of regional tectonics (e.g., Elliot \& Williams, 1988; Maltman, 1994a; Alsop et al., 2017, 2019). However, very few systematic fold analyses have been carried out for such folds (Woodcock, 1976; Farrell \& Eaton, 1987; Waldron \& Gagnon, 2011; Ortner \& Killian, 2016; Alsop et al., 2019). Deformation, often associated with recrystallisation, is the driving mechanism for folding in hard rocks, whereas folding within soft sediments is typically achieved due to relative structure variations depending upon the ratio between sediment cohesive strength and presence of pore fluids (Knipe, 1986; Ortner, 2007); with folds and shears being formed by hydroplastic deformation where cohesive strength exceeds fluid pressure. Waldron \& Gagnon (2011) realised that the intensity of lithification during folding could be estimated from the styles of folding in different mud and sand layers, and thus recognised soft-sediment folds. In spite of differences in the mechanism of folding for hard rock and soft sediments, the geometry of resultant folds is so close to one another that it is desirable to develop criteria to differentiate these various fold types (Alsop et al., 2017, 2019).

SSDS are caused by a number of driving forces such as gravitational instability, dewatering, liquefaction-liquidisation, overloading, wave-induced stress and reverse density gradient (Allen, 1984; Moretti et al., 2011; Owen \& Moretti, 2011). Synsedimentary extensional tectonics plays a vital role in the deformation mechanism and acts as driving forces for soft-sediment deformations during sed-
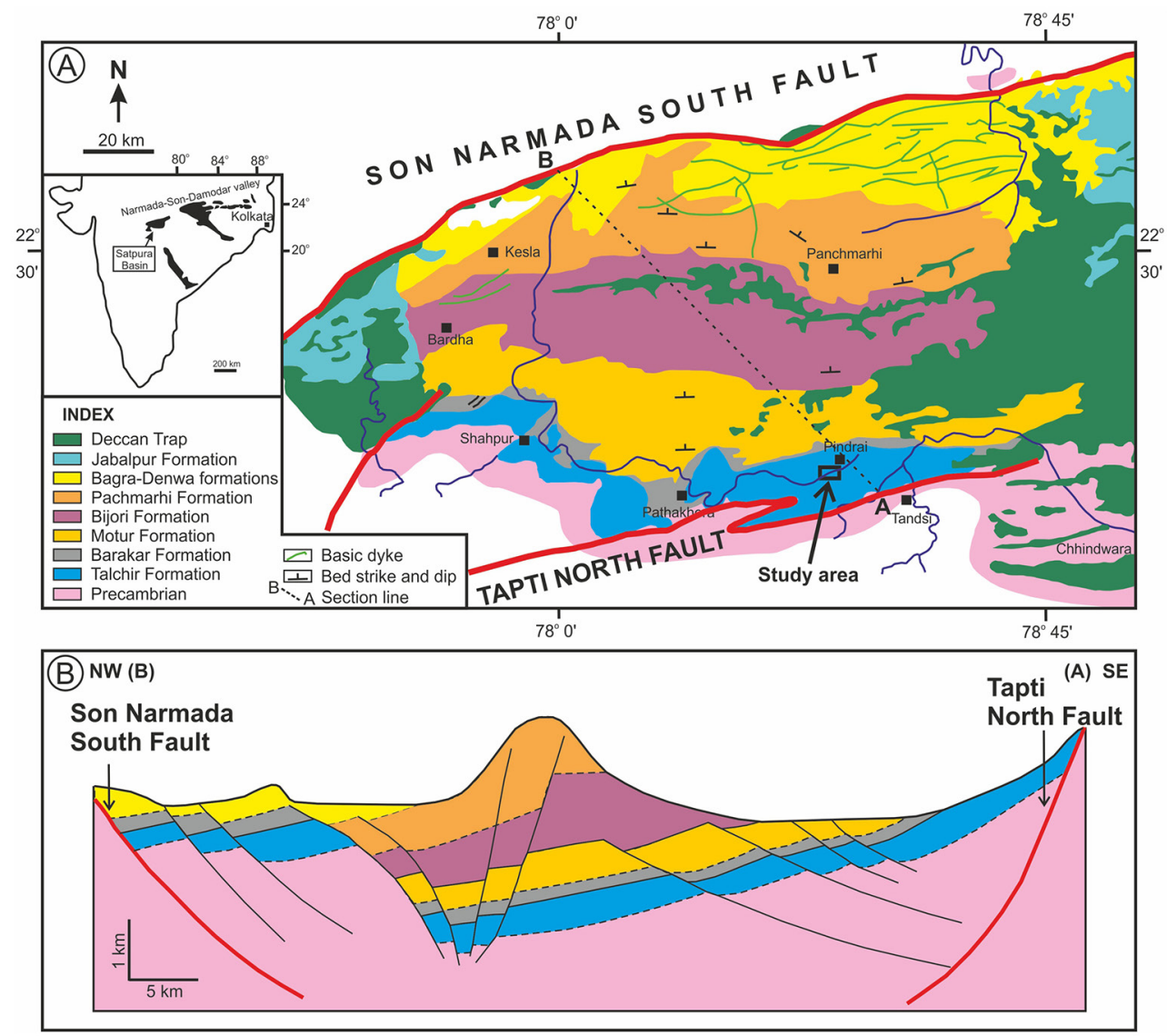

Fig. 1. A - Simplified geological map of the Satpura Basin, with basin-bounding faults and the location of the study area. Insert shows the distribution of Gondwana basins in the Indian peninsula, with indication of the Satpura Basin; B - Cross-section across basin-bounding faults of the Satpura Basin (modified after Chakraborty \& Ghosh, 2005). 
imentation or prior to lithification. The Gondwana basins of peninsular India have traditionally been considered as extensional rift basins with evidence of fault-controlled synsedimentary subsidence. The Satpura Gondwana Basin of central India is believed to be a pull-apart structure (Chakraborty \& Ghosh, 2005). Presence of slump folds within the basalmost Talchir Formation in the Satpura Basin provides evidence of synsedimentary tectonic processes.

The aim of the present paper is to analyse the range of fold styles created during soft-sediment deformation with techniques commonly applied in hard-rock deformation, their subsequent modification and orientation of palaeoslope, as well as to discuss the geological implication of the slumping event with respect to regional tectonics and evolution of the Satpura Basin.

\section{Geological framework of the basin}

The ENE-WSW trending Satpura Basin represents the most westerly among a series of basins occur- ring along Narmada-Son-Damodar valley of peninsular India (Fig. 1A). Rock successions, about 5,000 metres thick, range in age from Permian to Cretaceous and outcrop over an area of about 12,000 $\mathrm{km}^{2}$, within this basin. The Gondwana strata in the basin are subdivided into lower Talchir, Barakar, Motur and Bijori formations of Permian age and upper Pachmarhi, Denwa, Bagra and Jabalpur formations of Triassic to Cretaceous age. The pullapart structure of the basin is marked by two major ENE-WSW trending faults, i.e., the Son-Narmada South Fault (SNSF) in the north and the Tapti North Fault (TNF) in the south. Towards the west, the basin is limited by a NE-SW trending fault which links the strike-slip margins with an easterly vergence (Fig. 1A; Chakraborty \& Ghosh, 2005). The regional strike of the basin-filling strata is NE-SW. For a long time, the basin was believed to have had a northerly monoclonal dip $\left(\sim 5^{\circ}\right)$ throughout its evolution (Medlicott, 1873; Crookshank, 1936; Raja Rao, 1983; Casshyap \& Khan, 2000; Peters \& Singh, 2001; Chakraborty et al., 2003; Chakraborty \& Ghosh, 2005).
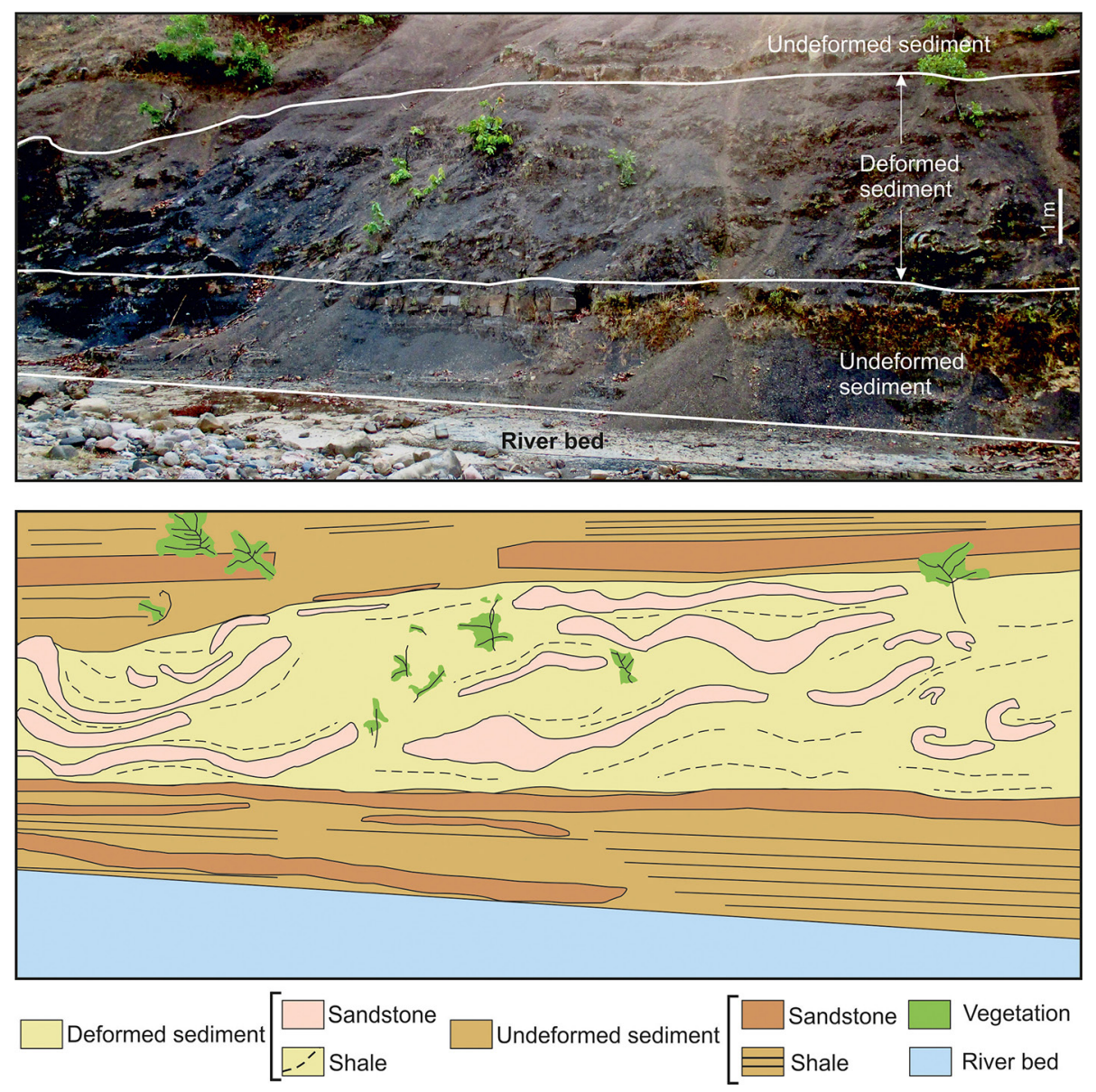

Fig. 2. Field photograph and line drawing showing slumped horizon intercalated between slightly deformed beds. 
There are number of intrabasinal normal faults that affected the basin-filling strata; these are predominantly: 1) an ENE-WSW trending set of faults subparallel to the basin margin faults in north and south and 2) both NE-SW and NW-SE trending cross-basinal faults. The basin has a typical asymmetrical half-graben configuration with thickening of the basin-filling sediments towards northerly dipping faults indicating fault-controlled synsedimentary subsidence (Fig. 1B) throughout its evolution, including during the deposition of the Lower Permian Talchir Formation that forms the focus of the present study. The thickening of hanging wall strata towards the basin-bounding fault planes is more evident in the Talchir sediments than in the overlying younger strata. This is due to the fact that the frequency of synsedimentary faults decreases towards the younger sediments (Raja Rao, 1983). The Talchir Formation is affected by faults more than the overlying sediments and crops out mostly along the southern part of the basin, with a few exposures in the northern part (Fig. 1A). Based on detailed facies studies, Chakraborty \& Ghosh (2008) suggested that the Talchir sediments represented a thick glaciofluvial fan deposit produced by resedimentation of debris dumped by glaciers along the shoreline. The SSDS present in the study area represent at distal glaciofluvial fan succession that is exposed in a tributary of the River Tawa, near the village of Pindrai.

As strata directly underlying and overlying the slumped unit remain horizontal, the area did not undergo tectonic deformation and slumps primarily originated as a result of a synsedimentary deformation event (Fig. 2). The difference in physical properties of the slumped unit with overlying and underlying strata leads to an impending instability of the rheologic interface, which may ultimately suffer deformation under the influence of triggering mechanism.

\section{Research methods}

Detailed field mapping, coupled with structural analysis of folds and thrust faults, form the basis of the present study. The pattern of fold axes and axial planes, as well as the fold vergence compared with fault dip data, have been analysed in order to determine the slump transport direction. Classic techniques of structural geology, applied in lithified rocks, for instance in dip-isogon analysis (Ramsay, 1967), refolding of folds and their post buckle modifications, have been used in the present study.

\section{Slump fold analysis}

The Talchir Formation exposed in the study area comprises (1) a basal boulder bed (2) massive, stratified diamictites and (3) an alternate succession of sandstone and shale (Fig. 3). The basal boulder bed is composed mainly of boulders of granite, granite-gneiss, schist, amphibolite, quartzite etc., with striated and facetted clasts. The massive diamictite is represented mainly by gravel-sized clasts of quartzite, granite, granite-gneiss etc., floating in a mud-rich matrix and appears as a matrix-supported, ungraded conglomerate. A crude stratification is discernible in stratified diamictites. Slump folds

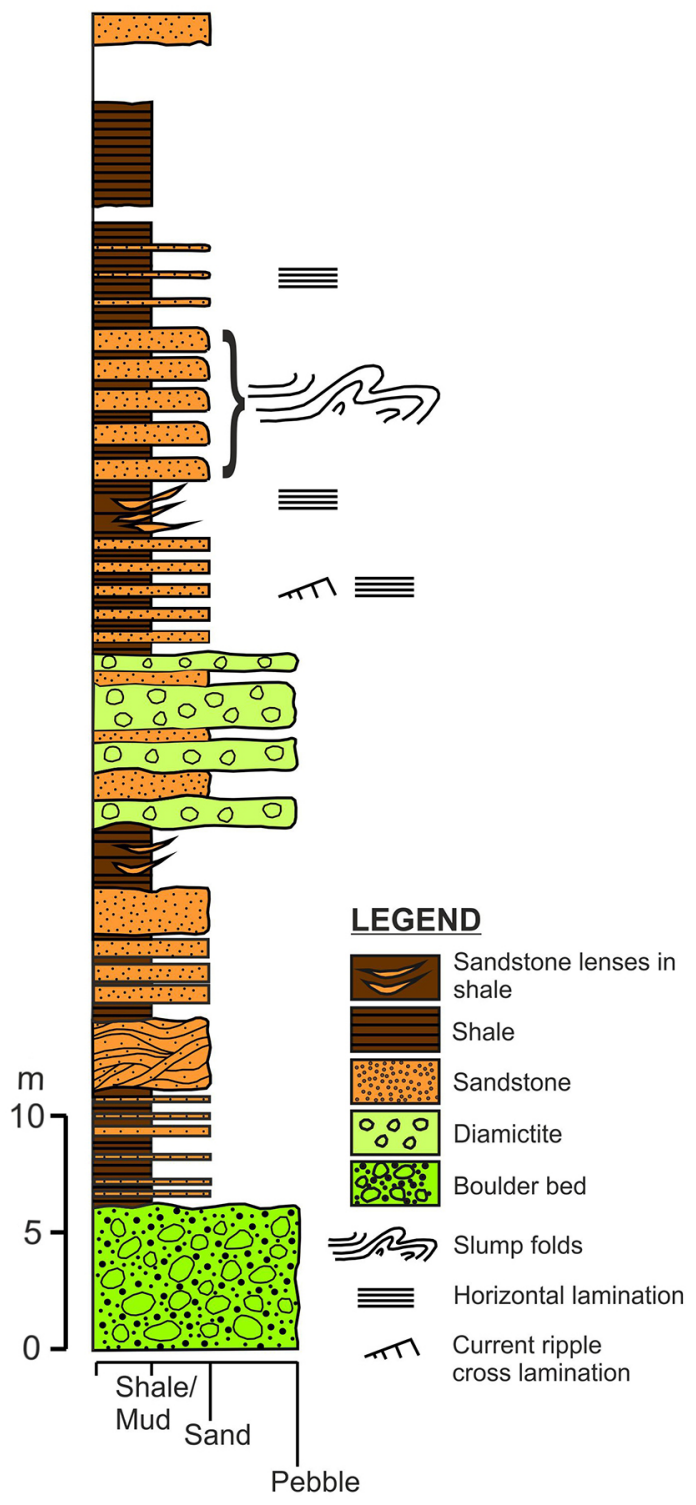

Fig. 3. Section showing a slumped intercalated succession of alternating sandstone- and shale-rich layers. Note the presence of parallel-laminated sediments immediately overlying and underlying the slumped unit. 
in the area are manifested within a $\sim 6-\mathrm{m}$-thick bilaminate succession of sandstone- and shale-rich layers which alternate and are exposed along the river bed for about $\sim 20 \mathrm{~m}$ (Figs 2,3). There are five sandstone and four shale beds. The thickness of individual sandstone beds varies between 17 and 90 $\mathrm{cm}$ and that of shale beds between 5 and $50 \mathrm{~cm}$. The contact with underlying and overlying horizons with the slumped unit are exposed and characterised by the presence of shale with thin lenses of sandstone beds of varying thickness, similar to the deformed unit. The sedimentary strata overlying and underlying the slumped unit are undeformed or less deformed (Figs 2, 3) and suggest that structures formed during the slumping event preserve their original geometry and did not suffer from or undergo modification. The presence of slump folds within a bilaminate succession of sandstone and shale simplifies the analysis of folding, because the competent beds are separated from one another by a weaker or less-competent host.

In order to determine the slump transport direction, fold characteristics such as the direction of the fold axis, axial planes and fold vergence with thrust present in the area, have been noted and analysed. Fold axes are NW-SE trending, while fold asymmetry varies along the exposure with SW-vergent folds predominating along the central and distal part of the slumped unit (Fig. 4). There are some NE-vergent folds, developed mostly in the proximal part of the slumped succession, but they are very few in number. Fold axial planes dip variably towards the NE, as do thrust planes. Analysis of fold axial planes, together with fold axis and thrust planes within slumps, suggests a southwesterly transport direction (Fig. 4).

\subsection{Dip-isogon analysis}

The dip-isogon technique is a widely used and well-established method for the classification of folds in lithified rocks. Elliot (1965) used the term dip-isogon for curves joining the points of equal dip on adjacent folded surface within a fold profile. Ramsay (1967) described this method in detail and used the thickness parameter for geometrical classification of mesoscopic folds. In this method, in the cross section of the fold, the orthogonal layer thickness $\left(t_{a}\right)$ is the perpendicular distance of the material between the tangent to the folded surfaces where each surface forms an angle $(90-a)$ with the axial surfaces. The value $t_{\alpha}$ varies with the angle of inclination $a$. The ratio of $t_{\alpha}$ to $t_{0}$ (where $t_{0}$ is the thickness of the two layers along the trace of axial surface on the folded profile), yields the parameter of normalised thickness

$$
t^{\prime}{ }_{a=} t_{\alpha /} t_{0}
$$

where $t^{\prime}$ relates to the fold shape and can be recorded graphically. The graphs of normalised thickness $\mathrm{t}^{\prime}{ }_{\mathrm{a}}$ against dip angle a allow to define a number of fold classes (Ramsay, 1967). Ramsay's Class 1 folds are represented by convergent isogons (Fig. 5B), while Class 2 folds have isogons consistently parallel to the axial planes and are represented by parallel isogons (Fig.5C) and Class 3 folds are represented by divergent isogons (Fig.5D).

In order to analyse slump fold geometries within the study area we have used the dip-isogon method (Fig.6). The dip-isogon analysis performed on the slump folds studied within the sandstone-rich layers shows a predominance of structures with convergent

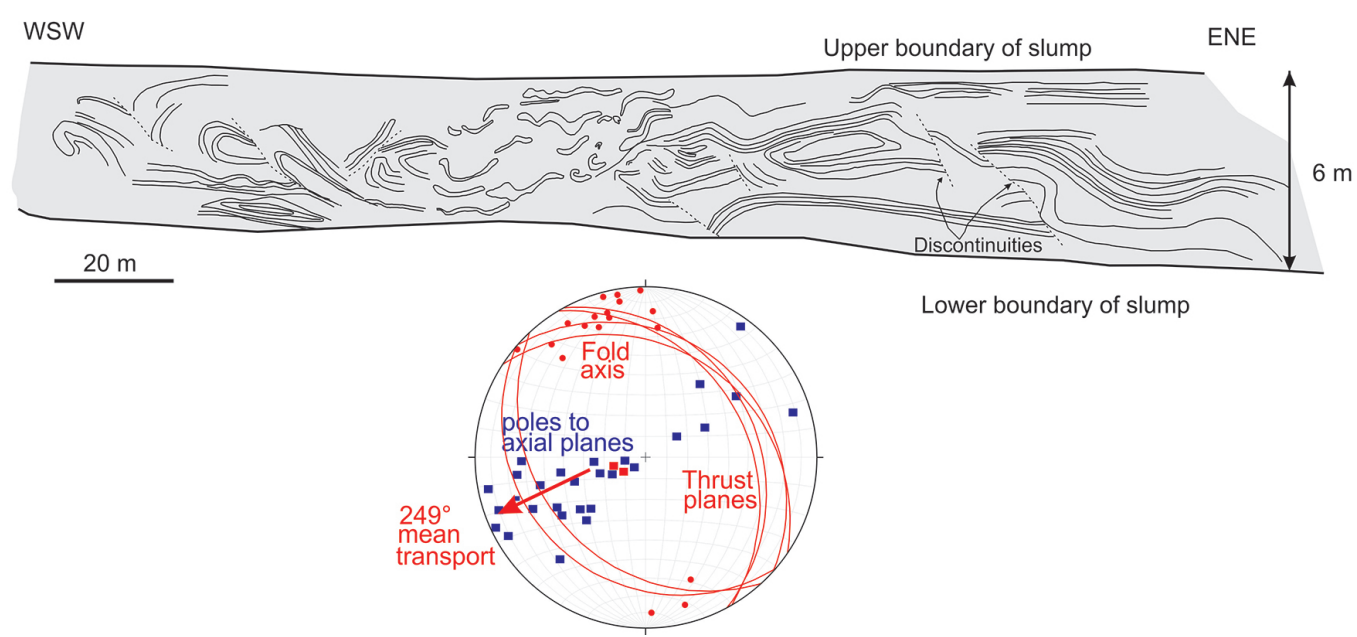

Fig. 4. Detailed mapping of the slumped unit, coupled with stereonet plot. In stereonet, fold axis (red circles), poles to axial planes (blue squares) and thrusts are shown as great red circles and poles as red squares. The measured slump transport is towards the west. 
isogon pattern (i.e., Class 1 geometry) and parallel dip-isogon pattern (i.e., Class 2 geometry) consistent with buckling (Fig. 6). The shale-rich layer displays Class 2 and 3 buckle folds (Fig. 6E, F). The more upright folds display a Class 1A, 1B or 1C buckle fold style in the proximal part of the slumped unit. Moving further towards the slump-transport direction, i.e., towards the west, the more inclined and recumbent folds are marked by Class 1C and Class 2 fold geometries, respectively. This suggests that folding in the study area suffered progressive deformation, resulting in rotation and tightening of fold axes towards the flow-transport direction, whereas the axial plane rotated into the plane of flow.
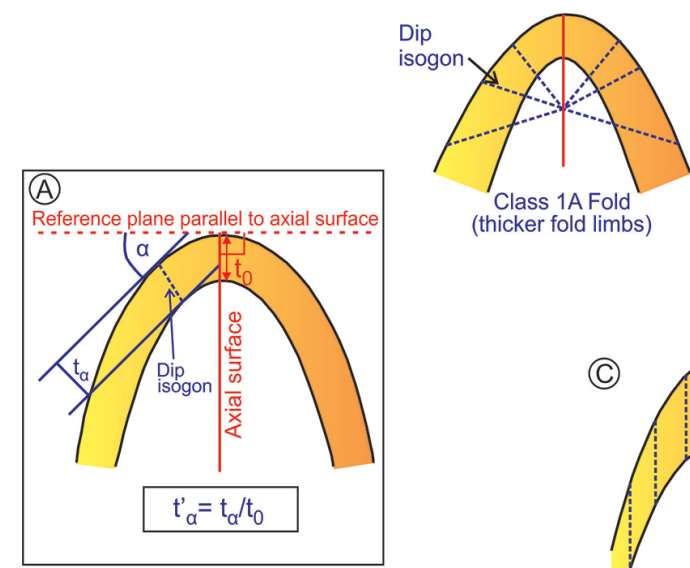

(B) Class 1 Folds - Convergent isogons
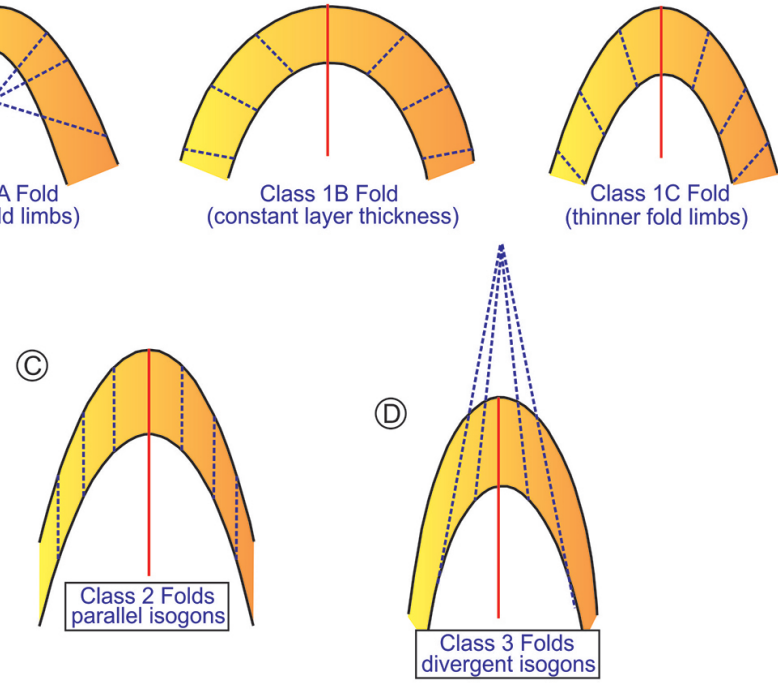

Fig. 5. A - Fold classification scheme after Ramsay (1967), based on dip isogon, layer thickness in fold hinge $\left(\mathrm{t}_{0}\right)$ and orthogonal thickness (ta) measured at various angles $(\alpha)$ to reference plane; $\mathbf{B}-$ Three main fold classes as Class 1 folds with convergent dip isogon with three subclasses (Class 1A, 1B and 1C); C - Class 2 folds with parallel- dip isogons; D - Class 3 folds with divergent dip isogons.
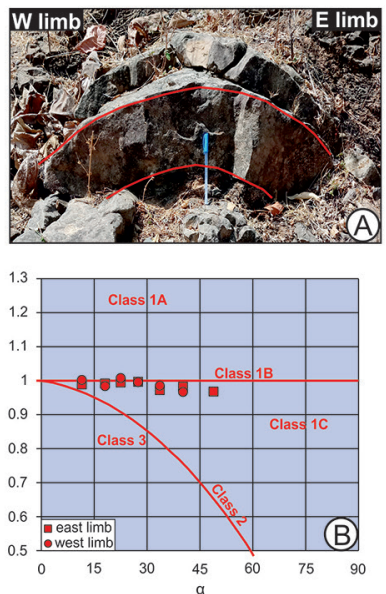

EAST
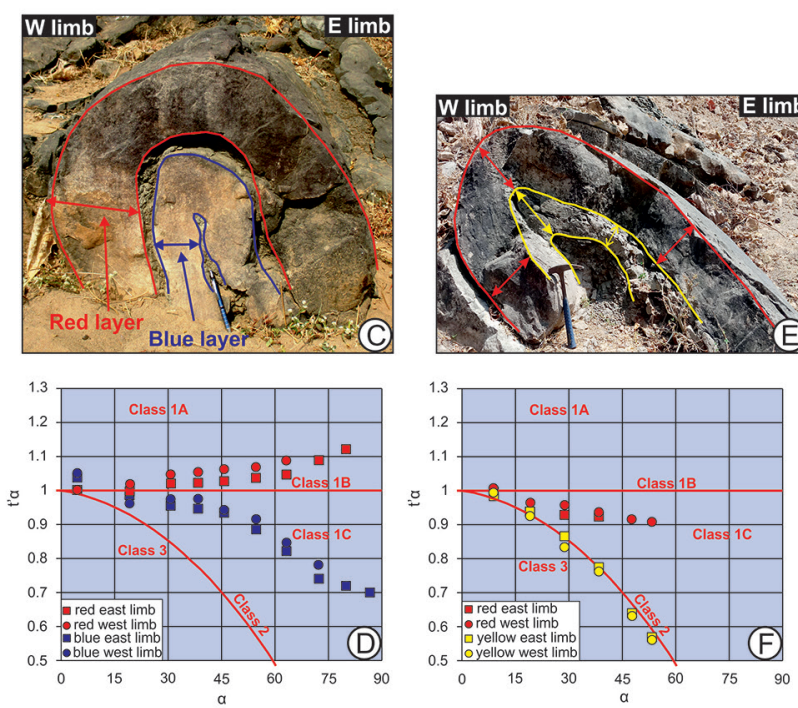

SLUMP DIRECTION
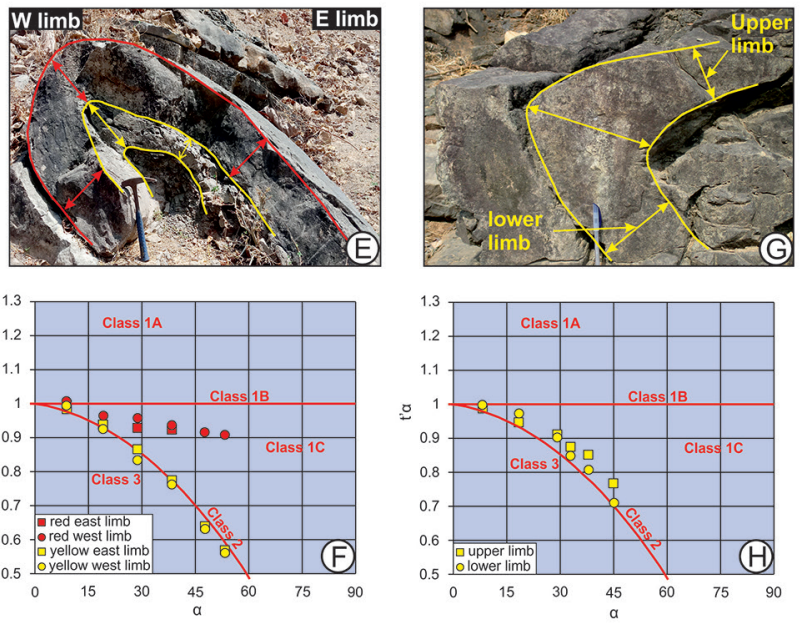

WEST

Fig. 6. Field photographs paired with $t^{\prime}$ a plots $(\mathbf{A} \& \mathbf{B}, \mathbf{C} \& \mathbf{D}, \mathbf{E} \& \mathbf{F}, \mathbf{G} \& \mathbf{H})$ towards down-slump transport direction. More upright folds display Class 1B or 1A fold styles. Inclined and recumbent folds show Class $1 \mathrm{C}$ and Class 2 geometries consistent with buckling. These folds display a progressive tightening with rotation and reduction in axial surfaces dip in a down-slope direction. 


\subsection{Refolding patterns within the slump}

On the basis of the relative orientation of the fold axes and axial surfaces developed during polyphase deformation of lithified rocks, Ramsay (1962, 1967) proposed a classification scheme for refolded folds. This scheme was developed for folds that were superimposed upon each other and considered to have developed during the same orogenesis. This includes four types of fold-interference patterns (Fig. 7):

- Type 0 Plane cylindrical fold, in which both the fold axis and the axial surface of early folds (F1) are planar and at high angles (Fig. 7A).

- Type 1 Plan non-cylindrical fold, in which the F1 fold axial surface is planar but the hinge line is curved within that plane (Fig. 7B).

- Type 2 Non-plane, non-cylindrical fold, in which both the axial surface and the hinge line of F1 folds are curved (Fig. 7C).

- Type 3 Non-plane, cylindrical fold, in which the hinge of F1 is straight but the axial surface of the F1 fold is curved (Fig. 7D).

This scheme of classification of superimposed folding or fold interference has commonly been applied in hard-rock deformation, and can be used in a wide variety of sizes and settings.

Within the slumped unit of the Talchir Formation studied (Fig. 7E, F), Type 1 and Type 3 folds are developed. In view of the fact that the folded slump levels are overlain by undeformed sediments formed following the slump event, this suggests that the refolding was completed during a single slump event.

\subsection{Post-buckle modification of slump folds}

Ramsay (1967) suggested that folds with Class 1C geometries may result from Class 1B parallel folds by flattening. Further similar folds apparently seen in naturally deformed rocks perhaps resulted from an initial buckling mechanism (Ramsay, 1967). Moreover, Farrell \& Eaton (1987) showed that, depending upon the homogeneous flattening acting normally or parallel to the original Class $1 \mathrm{~B}$ fold, may result in a Class 1C and Class 1A geometry. Hudleston (1973) documented that the simultaneous mechanism of buckling and flattening may yield folds with a Class $1 \mathrm{C}$ geometry, and hence there is no need for successive episodes of fold development, with folds formed through progressive deformation in slump. Alsop et al. (2019) suggested that post-buckle processes ranging from flattening, shearing to flow contributed to the final geometry of the slump folds. The initial buckle folds created by layer-parallel shortening related with pure shear is then progressively imposed with downslope-directed simple shear resulting in a

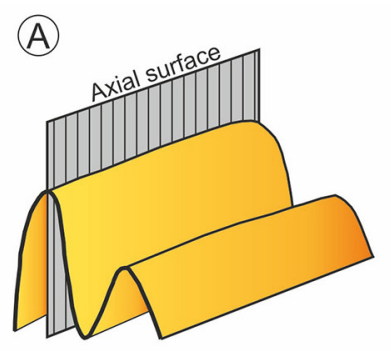

Type 0

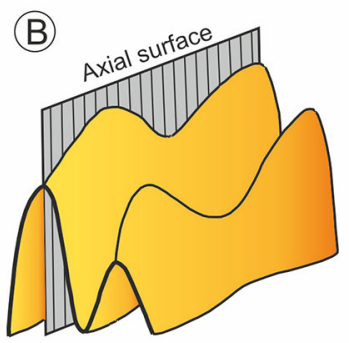

Type 1

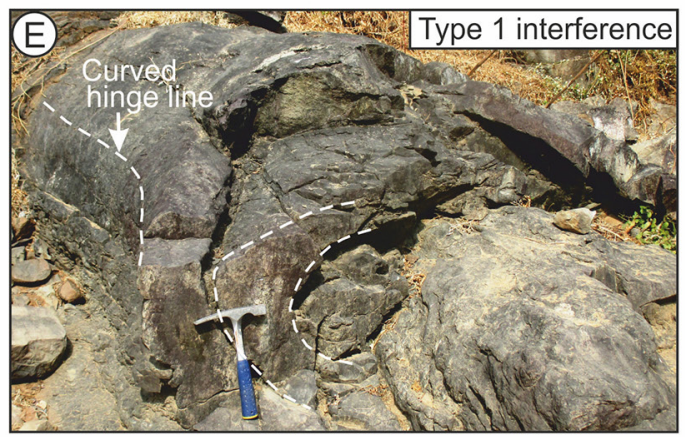

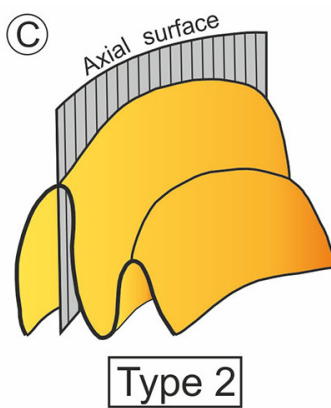
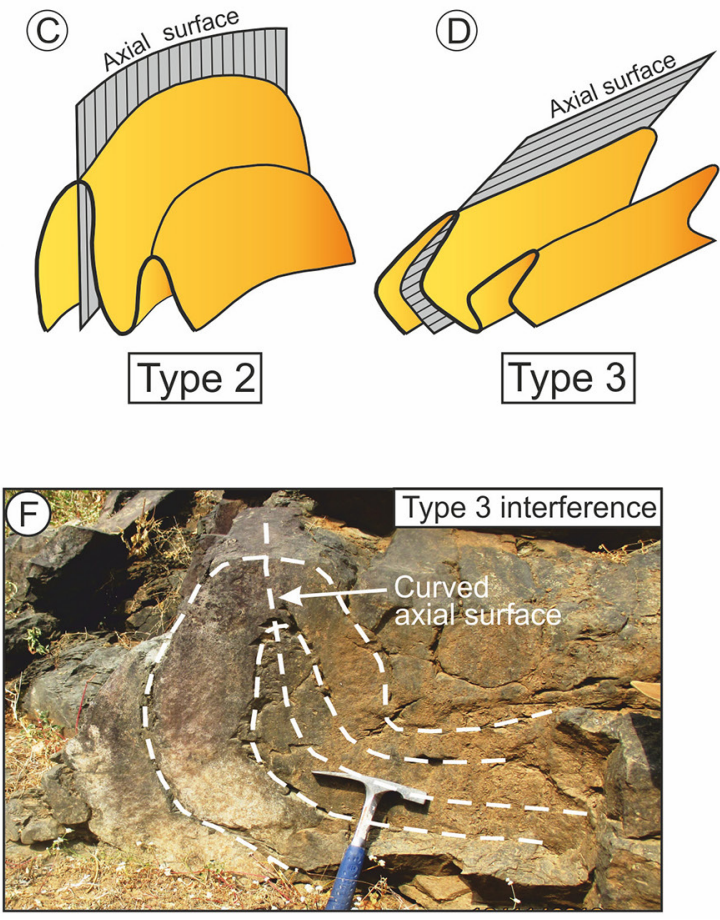

Fig. 7. A-D - Fold interference pattern (Type 0 to Type 3) based on orientation of fold axes and axial planes (after Ramsay, 1967; Ramsay \& Huber, 1987); E-F - Field photographs showing refolds within slumps in the study area. 


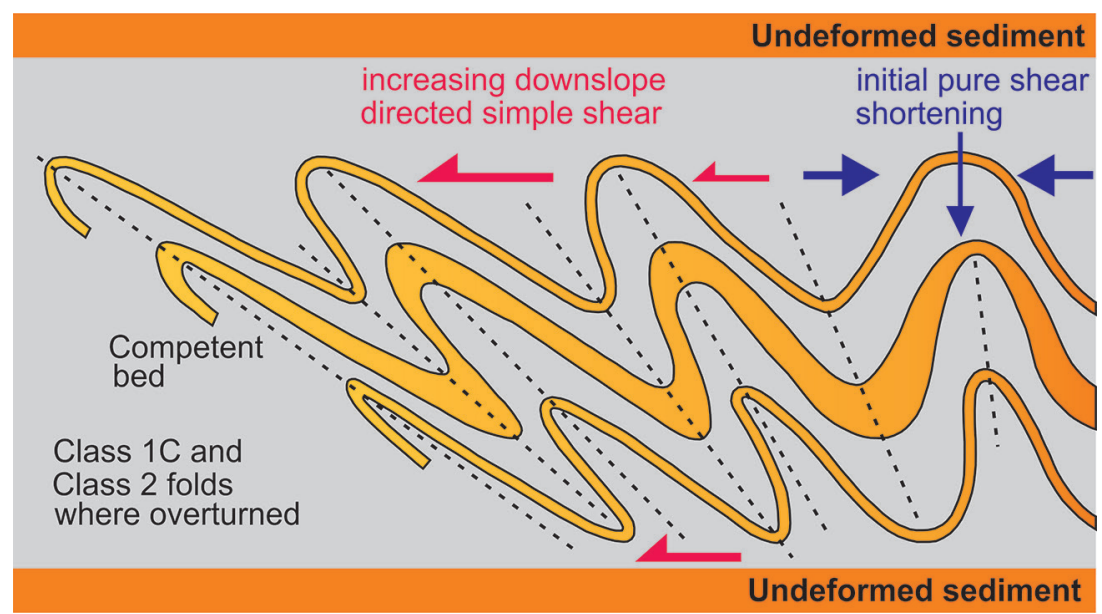

Fig. 8. Schematic diagram showing folding created during SSD of competent beds. range of fold geometries (Alsop et al., 2019) (Fig. 8). The progressive rotation and tightening of upright buckles to overturned folds in the area is in accordance with increasing downslope-directed, non-coaxially dominated deformation (Twiss \& Moores, 2007; Dasgupta, 2008).

\section{Discussion}

\subsection{Soft-sediment deformation structures}

Analysis of the dip-isogon in the present study shows that a variety of folds, ranging from Class $1(1 \mathrm{~A}, 1 \mathrm{~B}, 1 \mathrm{C})$ to Class 2 and Class 3 geometries, formed within the slumped unit. The more competent (i.e., sandstone - rich) layers show Class 1 and Class 2 geometries, while shale-rich layers (i.e., incompetent) display Class 2 and 3 geometries. Price \& Cosgrove (1990) demonstrated that such variable styles of folding allowed an individual fold to propagate further along its axial plane without encountering significant accommodation problems around the fold axes. The more upright folds display a Class 1 geometry consistent with buckling, created due to layer-parallel shortening associated with pure shear. The more inclined folds are characterised by Class 1C and the recumbent folds have Class 2 geometries. The initial pure shear, creating upright folds, was then progressively imposed and resulted in a range of fold geometries including more inclined and recumbent folds, with downslope-directed simple shear dominated by non-coaxial deformation.

Refold patterns created during deformation in lithified rocks were also recognised within slumps in the study area. Refolds within the slumped unit are truncated or overlain by undeformed sediments, suggesting that they formed through a single slump event and are not a product of the superposition of later events. Analysis of folds shows buckling to have been the predominant folding mechanism for slump folds present in the study area. Although hydroplastic particulate flow is the dominant mechanism for deformation in unlithified sediments, rather than recrystallisation in the deformation of lithified rock, the series of fold geometries produced are similar to each other.

\subsection{Regional tectonics and basin evolution}

All the traditional Gondwana basins of India have a graben or half-graben geometry. The Indian shield is a mosaic of a few Archaean cratonic blocks (Radhakrishna \& Naqvi, 1986) and all of the present-day Gondwana basins are located within the suture zone between these cratonic blocks. The Early Carboniferous to Late Permian saw a series of tectonic processes which are hypothesised to have controlled the reactivation of Precambrian weak zones in the Indian continent and to have resulted in basin formation, initially as "Sag-type" that were later on converted into rift or pull-apart type basins (Biswas et al., 1993; Biswas, 1999). A detailed study of the Indian basins has revealed that the sedimentation in the Gondwana basins of India evolved through a complex interplay of faulting, changes in sea level and climate. Chakraborty et al. (2003) suggested that all Gondwana basins in peninsular India developed under a bulk, roughly E-W, horizontal extension of the rigid Indian basement. The pull-apart Satpura Basin is considered to have developed above a releasing jog of a left-stepping strike-slip fault system defined by the SNSF and TNF in consequence to the sinistral displacement along the WSW-ENE (Chakraborty \& Ghosh, 2005) (Fig. 9).

The slump folds preserved in Lower Permian Talchir strata of the Satpura Basin offers an oppor- 
Fig. 9. Fault kinematics related to the formation of the Satpura Basin. Note that the basin initiated above a stepover of a left-stepping strike-slip zone as a result of sinistral fault motion, as suggested by Chakraborty \& Ghosh (2005).

tunity for understanding the palaeoslope of the basin and for outlining the evolutionary history of the basin. As previously noted, the study of slump folds and progressive fold evolution during slump events, has yielded a downslope, southwesterly direction. This suggest that the basin did not have a monoclinally northerly slope throughout its evolution. At the opening of pull-apart, the basin tilted and dipped towards the southwest. The southwesterly slope of the basin suggests that at the initiation of the Satpura Basin the cross-fault trending NE-SW, generated due to movement along boundary faults, was more active than the basin margin faults (Fig. 9). The synsedimentary faulting along this oblique slip cross-fault triggered the slumping event within the Talchir sediments in the basin (Fig. 9). Moreover, with progressive offset and pullapart of the master strike-slip faults, a thorough basinal lineament developed which divided the entire basin into two discrete grabens, separated by an intra-basinal horst. This may have resulted in a change of transport direction within the basin. The southwesterly palaeoslope of the slump sediment during Talchir deposition is evidence of the initial stage of pull-apart basin along oblique-slip fault linking master strike-slip faults, i.e., SNSF and TNF. With progressive overlapping of master strike-slip faults basin gradually tilted towards the north.

\section{Conclusions}

From the present study, the following conclusions can be drawn:

- All potential fold styles, ranging from Class 1A, $1 \mathrm{~B}$ and $1 \mathrm{C}$ to Class 2 and 3 geometries are developed within slumps in the study area.

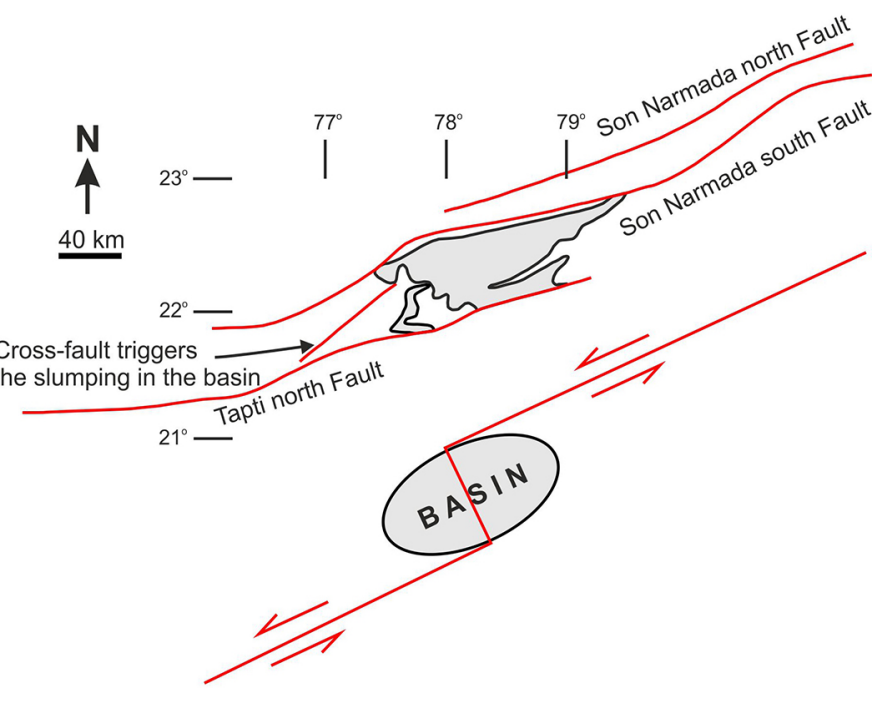

- The more competent, sandstone-rich layer displays Class 1 and Class 2 geometries, while the more incompetent, shale-rich layer has Class 2 and Class 3 geometries.

- Upright folds created by pure shear underwent rotation of axial planes and fold axes during progressive simple shear-dominated deformation as the slump passes downslope under gravity.

- We have recognised a similar range of refold forms in slumps in comparison to deformation in hard rocks.

- The oblique slip fault linking the master strikeslip faults of the basin was more active at the opening of the basin and induced slumping during Talchir sedimentation.

- The palaeoslope of the Satpura Basin was not uniformly north dipping but continuously changed throughout its evolution.

\section{Acknowledgements}

We express our sincere thanks to Shri G.V. Vidyasagar (Additional Director General and HoD, Geological Survey of India, Nagpur) for extending the necessary facilities to carry out the present work, to Dr Sandip Kumar Roy and Dr Anjan Rai Choudhuri (Director, GSI) for valuable technical discussions and to anonymous reviewers for their constructive and thoughtful comments, which helped to improve the quality of the manuscript.

\section{References}

Alfaro, P., Delgado, J., Estevez, A., Molina, J.M., Moretti, M. \& Soria, J.M., 2002. Liquefaction and fluidization 
structures in Messinian storm deposits (Bajo Segura Basin, Betic Cordillera, southern Spain). International Journal of Earth Sciences 91, 505-513.

Allen, J.R.L., 1984. Sedimentary Structures: Their Character and Physical Basis. Unabridged two-volume edition. Developments in Sedimentology 30. Elsevier, Amsterdam, 593 and $663 \mathrm{pp}$.

Allen, J.R.L., 1986. Earthquake magnitude-frequency, epicentral distance, and soft sediment deformation in sedimentary basins. Sedimentary Geology 46, 67-75.

Alsop, G.I., Marco, S., Levi, T. \& Weinberger, R., 2017. Fold and thrust systems in Mass Transport Deposits. Journal of Structural Geology 94, 98-115.

Alsop, G.I., Weinberger, R., Marco, S. \& Levi, T., 2019. Folding during soft-sediment deformation. Journal of Geological Society 487, 81-104.

Biswas, S.K., 1999. A review on the evolution of rift basins in India during Gondwana with special reference to western Indian basins and their hydrocarbon prospects. [In:] Sahni, A. \& Loyal, R.S. (Eds): Gondwana Assembly: New Issues and Perspectives. Proceedings of Indian National Science Academy. Special Issue, 261-283.

Biswas, S.K., Bhasin, A.L. \& Ram, J., 1993. Classification of Indian Sedimentary Basins in the Framework of Plate Tectonics. Proceedings of the Second Seminar in Petroliferous Basins of India 1, 1-46.

Byun, U.H., Van Loon, A.J., Kwon, Y.K. \& Kyoungtae, K., 2019. A new type of slumping-induced soft-sediment deformation structure: the envelope structure. Geologos $25,111-124$.

Casshyap, S., \& Khan, A., 2000. Tectono-sedimentary evolution of the Gondwanan Satpura Basin of central India: evidence of pre-Trap doming, rifting and palaeoslope reversal. Journal of African Earth Science, 31, 65-76.

Chakraborty, C. \& Ghosh, S.K., 2005. Pull-apart origin of the Satpura Gondwana Basin, central India. Journal of Earth System Sciences 114, 259-273.

Chakraborty, C. \& Ghosh, S.K., 2008. Pattern of sedimentation during the Late Paleozoic, Gondwanaland glaciations: An example from the Talchir Formation, Satpura Gondwana Basin, Central India. Journal of Earth System Sciences 117, 499-519.

Chakraborty, C., Ghosh, S.K. \& Chakraborty, T., 2003. Depositional Record of Tidal-Flat Sedimentation in the Permian Coal Measures of Central India: Barakar Formation, Mohpani Coalfield, Satpura Gondwana Basin. Gondwana Research 6, 817-827.

Crookshank, H., 1936. Geology of the northern slopes of the Satpura between the Moran and Sher rivers. Memoir of Geological Survey of India 66, 173-381.

Dasgupta, P., 2008. Experimental decipherment of the soft sediment deformation observed in the upper part of the Talchir Formation (Lower Permian), Jharia Basin, India. Sedimentary Geology 205, 100-110.

Elliot, D., 1965. The quatitative mapping of the directional minor structures. The Journal of Geology 73, 865-880.

Elliot, C.G. \& Williams, P.F., 1988. Sediment slump structures: a review of diagonastic criteria and application to an example from Newfoundland. Journal of Structural Geology 10, 171-182.
Ettensohn, F.R., Rast, N. \& Brett, C.E., 2002. Ancient seismites. Geological Society of America Special Paper 359, 177-190.

Farrell, S.G. \& Eaton, S., 1987. Slump strain in the Tertiary of Cyprus and the Spanish Pyrenees. Definition of paleoslopes and models of soft sediment deformation. [In:] Jones, M.F. \& Preston, R.M.F. (Eds): Deformation of Sediments and Sedimentary Rocks. Geological Society London, Special Publications 29, 181-196.

Hubert-Ferrari, A., El-Ouahabi, M., Garcia-Moreno, D., Avsar, U., Altinok, S., Schmidt, S. \& Cagatay, N., 2017. Earthquake imprints on a lacustrine deltaic system: the Kürk Delta along the East Anatolian Fault (Turkey). Sedimentology 64, 1322-1353.

Hudleston, P.J., 1973. An analysis of 'single layer' folds developed experimentally in viscous media. Tectonophysics 16, 189-214.

Knipe, R.J., 1986. Deformation mechanism path diagrams for sediment undergoing lithification. [In:] Moore, J.C. (Ed.): Structural Fabric in Deep Sea Drilling Project Cores From Forearcs. Geological Society of America Memoirs 166, 151-160.

Leeder, M.R., 1987. Sediment deformation structures and the palaeotectonic analysis of sedimentary basins, with a case-study from the Carboniferous of northern England. [In:] Jones, M.E. \& Preston, R.M.F. (Eds): Deformation of Sediments and Sedimentary Rocks. Geological Society, London, Special Publication 29, 137146.

Lowe, D.R., 1975. Water-escape structures in coarsegrained sediments. Sedimentology 22, 157-204.

Maltman, A., 1984. On the term soft-sediment deformation. Journal of Structural Geology 6, 589-592.

Maltman, A., 1994a. Deformation structures preserved in rocks. [In:] Maltman, A. (Ed.): The Geological Deformation of Sediments. Chapman \& Hall, London, 261307.

Maltman, A., 1994b. Introduction and overview. [In:] Maltman, A. (Ed.): The Geological Deformation of Sediments. Chapman \& Hall, London, 1-35.

Maltman, A.J., Hubbard, B. \& Hambrey, M.J. (Eds), 2000. Deformation of Glacial Materials. Geological Society of London. Special Publication 176.

Mazumder, R., Van Loon, A.J. \& Arima, M., 2006. Soft-sediment deformation structures in the Earth's oldest seismites. Sedimentary Geology 186, 19-26.

Mazumder, R., Van Loon, A.J., Malviya, V.P., Arima, M. \& Ogawa, Y., 2016. Soft-sediment deformation structures in the Mio-Pliocene Misaki Formation within alternating deep sea clays and volcanic ashes (Miura Peninsula, Japan). Sedimentary Geology 344, 323-335.

Meddlicott, H.B., 1873. The Shahpur Coalfield with a note on coal exploration in Narmada region. Records of Geological Survey of India 18, 65-86.

Moretti, M., Owen, G. \& Tropeano, M., 2011. Soft-sediment deformation induced by sinkhole activity in shallow marine environments: a fossil example in the Apulian foreland (southern Italy). Sedimentary Geology 235, 331-342.

Obermeier, S.F., 1996. Using liquefaction-induced features for paleoseismic analysis. [In:] McCalpin, J.P. 
(Ed.): Paleoseismology. International Geophysics Series 62, 331-396.

Ortner, H., 2007. Styles of soft-sediment deformation on top of a growing fold system in the Gosau Group at Muttekopf, Northern Calcareous Alps, Austria: slumping versus tectonic deformation. Sedimentary Geology 196, 99-118.

Ortner, H. \& Kilian, S., 2016. Sediment creep on slopes in pelagic limestones: Upper Jurassic of Northern Calcareous Alps, Austria. Sedimentary Geology 344, 350-363.

Owen, G. \& Moretti, M., 2011. Identifying triggers for liquefaction-induced soft-sediment deformation in sands. Sedimentary Geology 235, 141-147.

Perucca, L.P., Godoy, E. \& Pantano, A., 2014. Late Pleistocene-Holocene earthquake-induced slumps and soft-sediment deformation structures in the Acequion River valley, Central Precordillera, Argentina. Geologos 20, 147-156.

Peters, J., \& Singh, S.K., 2001. Satpura basin - an example of pre-rift, syn-rift, post-rift Gondwana sedimentation in India. Journal of Geological Society of India 57, 309-320.

Pratt, B.R., 1994. Seismites in the Mesoproterozoic Altyn Formation (Belt Supergroup), Montana: a test for tectonic control of peritidal carbonate cyclicity. Geology 22, 1091-1094.

Price, N.J. \& Cosgrove, J.W., 1990. Analysis of Geological Structures. Cambridge University Press, Cambridge, 502 pp.

Radhakrishna, B.P. \& Naqvi, S.M., 1986. Precambrian continental crust of India and its evolution. The Journal of Geology 94, 145-166.
Raja Rao, C.S., 1983. Coalfields of India. Vol. III. Coal resources of Madhya Pradesh and Jammu and Kashmir. Geological Survey of India Bulletin Series A, 45, 248-285.

Ramsay, J.G., 1962. Interference patterns produced by the superposition of folds of 'similar' type. Journal of $\mathrm{Ge}$ ology 60, 466-481.

Ramsay, J.G., 1967. Folding and Fracturing of Rocks. McGraw Hill, New York, 568 pp.

Ramsay, J.G. \& Huber, M.I., 1987. The Techniques of Modern Structural Geology. Vol. 2. Folds and Fractures. Academic Press, London, 391 pp.

Seilacher, A., 1969. Fault-graded beds interpreted as seismites. Sedimentology 13, 155-159.

Twiss, R.J. \& Moores, E.M., 2007. Structural Geology. $2^{\text {nd }}$ ed. W.H. Freeman \& Company, New York, 736 pp.

Üner, S., 2014. Seismogenic structures in Quaternary lacustrine deposits of Lake Van (eastern Turkey). Geologos 20, 79-87.

Van Loon, A.J., 2009. Soft-sediment deformation structures in siliciclastic sediments: an overview. Geologos 15, 3-55.

Van Loon, A.J. (Ed.), 2014. Seismites and their soft-sediment deformation structures. Geologos 20, 61-166.

Waldron, J.W.F. \& Gagnon, J.F., 2011. Recognizing soft-sediment structures in deformed rocks of orogens. Journal of Structural Geology 33, 271-279.

Woodcock, N.H., 1976. Structural style in slump sheets: Ludlow Series, Powys, Wales. Journal of Geological Society, London 132, 399-415.

Manuscript submitted: 17 May 2021 Revision accepted: 1 August 2021 